\title{
AN EDUCATIONAL APPLICATION OF MOBILE PHONES TO IMPROVE THE EMBROIDERY SKILLS OF USING THE HOME SEWING MACHINES TECHNIQUES FOR THE STUDENTS
}

\author{
Rania Shawky Mohammed GHAZI*
}

Fashion Design Department, College of Designs and Arts, Umm Al-Qura University, KSA

\begin{abstract}
Machine embroidery represents a branch of applied arts, and its study combines the aspect. Electronic teaching aesthetic and skill. Machine embroidery is an extension of hand embroidery is necessary. A mobile app who works in machine embroidery to be knowledgeable and familiar with hand embroidery and its techniques. Machine embroidery and stitch designations so that he can use machine embroidery. In addition, it turns out by teaching.

Knitting machines for female students' Automatic embroidery course that there is a problem in the absence of references, electronic educational lessons, or multiple media. Retrieval of what was studied in the classroom, which caused a decrease in the skill level of some students because the course depends on the actual practice in the classroom, and from this point it came Interest in the research topic And designing an "educational application for mobile phones to develop the skills of using machine embroidery techniques for students using home machines" in order to continuously monitor the progress of students' skills in the use of machine embroidery techniques.

Keywords

Educational Application, Mobile Phones, The Embroidery Skills, The Home Sewing, Machines Techniques, Students.
\end{abstract}

\section{Introduction}

The research is concerned with providing educational lessons for the mobile phone as one of the methods developed and supported by interactive multimedia in the subject of automatic embroidery to spread awareness of the skills of automatic embroidery, which enhances remote education for students who are not able to actually attend in the classroom, and it also provides a two-way communication method so that the student can To rely on its independence in learning, as it provides education to those who cannot obtain it otherwise. It aims to support e-learning With an applied program to help students in the machine embroidery course, and to provide an electronic curriculum remotely with the possibility of immediate retrieval, as the course depends on direct education and actual practice in the classroom.

In machine embroidery: (work the addition or abscission The art of embroidery is one of the first arts that he used The method of taxation is the method of (Osmox) the human being in the decoration of his clothes and one of the finest types of arts. It became clear through the teaching of the students the automatic embroidery course that it occupied a very important position, whether for decorating clothing pieces that there is a problem in the absence of references or educational lessons or for decorating homes, so the forms of embroidery vary and appeared Embroidery is an electronic or multi-media process. Retrieval of both manual and automatic embroidery.

And since the machine embroidery keeps pace with his studies in the classroom, which caused a decrease in the level of the modern era, so it became one of the modern fine arts, as the skills of some students, given that the course depends on using modern machines, it is easy to extract the designs actual practice in the teaching room, and from this point of view came the fast decorative Using weaving, motifs and threads, interest in the research topic and designing an electronic educational application that is consistent with development. Skills of

*Corresponding author: callcenter@uqu.edu.sa 
using machine embroidery techniques for students. Machine embroidery represents a branch of applied arts using household machines, in order to follow up on progress and its study combining aesthetic and skillful aspects.

Also, the skills of female students in the permanent use of embroidery techniques. Machine embroidery is considered an extension of manual embroidery, so the machine, which led to the design of an educational program in the form of the program of the machine embroidery worker, must be aware and knowledgeable about the application of the mobile phone for ease of use and to develop skills in hand embroidery, its methods and the names of stitches so that he can From automatic embroidery for female students. The use of machine embroidery. It is some of the methods that were used.

\section{Research Problem}

1- To what extent is the aesthetic appearance achieved and the extent to which the automatic program is appropriate by using household machines to attract students' attention and stimulate focus?

2- How effective is job performance to acquire skills? There are many previous studies that have benefited research? Concerning the use of machine embroidery techniques as stated in

3- How clear are the educational steps in the stages of implementation of Azza Abd Al-Alim Sarhan's study entitled: Andalusian style motifs and their employment in enriching clothes using the method of embroidery). “The Effectiveness of the Machine Embroidery Techniques Program?” Training for developing students 'skills in embroidering fabrics

4- How effective is the use of video films and poison media by using pharaonic designs to implement multiple products in teaching machine embroidery techniques? Tourism "The research aims to raise the performance of female students in embroidery.

\section{The Goals of Research}

The research aims to support e-learning with an application program for mobile phones to help students in the automatic course. The study is concerned with learning about the Andalusian style, especially the motifs and methods used, and changing them to use machine embroidery.

Providing an electronic curriculum that supports female students remotely with clothes with advanced techniques on automatic embroidery machines. Development and support for women's clothes and their supplements. It also aims to raise the possibility of immediate retrieval of information, as the course depends on direct education and practice the level of aesthetic value of the clothes in addition to supporting the Saudi national economy In light of the Kingdom's accession to the actual organization in the classroom.

\section{Research Importance}

The research is concerned with providing educational lessons for the mobile phone as one of the competition, the study of Noura Mohsen Al-Otaibi entitled: "The aesthetics of folk art decorations, the cat and the engraving, the methods developed and supported by interactive multimedia on the subject of automatic embroidery to spread awareness and special skills of textiles using the technique of automatic embroidery." She is interested in using the decorations of folk art. With techniques of machine embroidery by machine embroidery, which enhances distance education for female students who are not able to actually attend in the classroom.

It also enriches the aesthetics of textiles and clothing, a study of Lamia providing a two-way means of communication so that the student can present Hassan Ali with the title: "The effect of automatic embroidery techniques on It depends on its independence in learning, as it provides education to the appearance of satin fabrics which aims to identify the effect of a difference (embroidery stitch density - type of thread, thickness of the 
material for those who cannot obtain it in another way.

\section{Research Methodology}

On the appearance of satin fabrics and their embroidery mechanically, and this research follows the descriptive approach to survey the views of each of the identification of the most appropriate techniques of machine embroidery on fabrics, and the investigation of university professors, specialists, students, and workers in good appearance, the study of Azza Abdel-Alim - Radwa Mustafa, entitled:

"Creating applications from samples prior to the labor market in knowing the efficiency of using the educational application. Preparing for the design and embroidery course to enrich the furnishings of the development room. Automated embroidery skills and an experimental approach in implementing the child." The research aims to use pre-prepared samples of the educational program.

\section{Limitations of Research}

In the course on automatic embroidery in the work of aesthetic enrichment units, the research is limited to the use of household machines only, and children's furniture, and as stated in the study of Hatem Fathi - Miral Adel Shibl - Naglaa Taima entitled: "The effect of a difference in machine embroidery. Some factors of automatic embroidery on functional properties.

The aesthetic fabrics are mixed (cotton / linen) and produced in combinations. The study was conducted by surveying a sample of different textile specialists, which aims to study the effect of some clothing and textile factors and faculty members in the Department of Fashion Design, and a sample of junior students in the field of embroidery design on the functional and aesthetic properties using fashion. Faculty of Design at Umm Al-Qura University, in addition to different textile compositions for blended fabrics (cotton / linen) working in the business sector and the market Equivalent to (44 different textural compositions), and Ola Abdellah-Rania Haykal's study entitled: "A website for presenting the artistic methods of a person." To fix various embroidery materials with hand techniques through research tools.

A questionnaire form to assess the effectiveness of the program in promoting the Internet, "which aims to develop new technical methods in the skill of junior students in the automatic embroidery course, fixing embroidery materials from lobes and stones in new ways, measuring the skill performance before and after using the application, and preparing a website to display these techniques for the electronic service." And hobbyists and workers in the field.

After presenting the statistical, descriptive and practical analysis of the evaluation results, we can confirm the fulfillment of the hypothesis of the study, which is the possibility of benefiting from the application in the field of education, training, projects and marketing for the benefit of dealers.

\section{Recommendations}

The study recommends preparing specialized educational software that helps enrich the educational process with feedback to the learner And the use of media in the work of educational software because of its great impact on attracting the attention of the learner.

\section{References}

1- Hatem Fathy, Miral Adel Shibl, Naglaa Taima - "The effect of the difference of some automated embroidery agents on the functional and aesthetic properties of fabrics mixed (cotton / linen) and produced with different textile compositions" - Published research - Journal of Science and Arts - Helwan University -2008 CE.

2- Khaira Awad Al-Zahrani "Study of the Andalusian style motifs and their use in enriching clothing using the 
technique of machine embroidery." Unpublished PhD Thesis - College of Education and Home Economics in Makkah Al-Mukarramah - Umm Al-Qura University -2008 CE.

3- Rania Shawqi Muhammad Ghazi "The use of the information network as one of the important educational methods in the field of clothing design." Unpublished MA Thesis - Faculty of Home Economics - Menoufia University. 2008 CE.

4- Ramas Abdul Hamid Mustafa Muhammad "Study of the factors affecting the embroidery of some raw materials used for clothing and its accessories and its impact on the level of product quality" - Unpublished Master Thesis - Faculty of Specific Education - Benha University -2012 m.

5- Azza Abdel-Alim, Radwa Mustafa, "Creating applications from pre-prepared samples for the design and embroidery enrichment course, children's room furnishings" - published research - Journal of Specific Education Research - Mansoura University - 2012 AD.

6 - Azza Abdel-Alim Sarhan, "The Effectiveness of a Training Program to Develop Female Students' Skills in Embroidering Opison Fabrics Using Pharaonic Designs to Implement Tourism Products" - Published research Journal of Specific Education Research, Mansoura University - 2012

7- Adel Abdel Moneim Abdullah Abu Khazim "combining the jacquard style with embroidery to create innovative designs for upholstery fabrics." Published Research- Humanistic Architecture, Art \& Science Journal - Volume $(15)^{Y} \cdot$ I - m. - Ola Youssef Abdallah, Rania Hosni Heikal, "A website that displays the technical methods of installing various embroidery materials using hand techniques via the Internet" - published research - the fifteenth first Arab international conference of home economics entitled: Home Economics and Youth Issues, Faculty of Home Economics - University of Menoufia, 2013 AD.

8- Aziza Ahmad Muhammad al-Aqmi, Hoda Abdul Aziz Muhammad Muhammad al-Sayed, "Automated embroidery technology for industrial leather and its impact on the quality of women's clothing production" published research - Alexandria Journal of (Agricultural Volume 61), Issue 2, p. 7: 1112-2018.

9- Lamia Hassan on "The Effect of Machine-Embroidery Techniques on the Appearance of Satin Fabric" Published research - Journal of Specific Education Research, Mansoura University - Volume (14), pp. 75 : 94 2008. 11

10- Naglaa Madi and Rasha Al-Gohary "A new vision to enrich the aesthetic aspect of the clothes of university students in the style of lace embroidery." Published Research- Journal of Studies and Research. Science and Arts - Volume Twenty Six, Issue Four - 2014 AD. - Noura Muhsin Al-Otaibi, a summary of the decorations of folk art (the cat and the inscription on textiles using the technique of machine embroidery "- unpublished PhD thesis College of Designs - Umm Al-Qura University 92013 AD.

11- Nawal bint Hamad Muhammad al-Jaad, "E-learning and its support for democracy and education" - published research - The World of Education magazine. - https://en.wikipedia.org/wiki/Sewing m achine_needle

Received: February 12, 2018

Accepted: April 27, 2018 